\title{
Morphometric and Genetic Variation of Six Seed Sources of Azadirachta excelsa (Jack) Jacobs
}

\begin{abstract}
Isozyme variability was examined in six seed sources representing the Azadirachta excelsa on two provenance trials in Batu Arang (Selangor, Malaysia) and Merchang (Terengganu, Malaysia). A concomitant study of morphometric variation revealed a slight variation in leaf morphology extending from quantitative to qualitative characteristics. The existence of this small variation presented an ideal opportunity to examine the genetic variation of these seed sources collected in Bukit Lagong and Manong (West Coast of P. Malaysia), Pengkalan Arang and Pasir Mas (East Coast of P. Malaysia), Semengoh (East Malaysia) and Narathiwat (Thailand). Nineteen enzyme systems were used to determine the genetic variation among seed sources using isozyme analysis. Allelic frequency data indicated little differentiation between seed sources. The mean values of observed heterozygosity (Ho) varied from 0.0229 (Pengkalan Arang) to 0.0451 (Bukit Lagong) whereas the mean values expected heterozygosity (He) varied from 0.0575 (Pengkalan Arang) to 0.0983 (Manong). The percentages of proportion polymorphic loci were found to vary between $31.43 \%$ (Pengkalan Arang and Pasir Mas) and 42.86\% (Bukit Lagong and Manong). Genetic identities according to Nei ranged from 0.7727 to 0.9999 . Despite these high levels of genetic similarity, the populations appeared to be highly inbred as indicated by positive mean of FIS and FIT values with the mean values of 0.5643 and 0.8038 .
\end{abstract}

Keyword: Azadirachta excelsa, morphology, seed sources, polymorphic 